\title{
What Goes around Comes around,
}

\section{Descendants Harm the Family Firm following Perceived Injustice}

\begin{abstract}
A pitfall in succession is the just allocation of the family business to the descendants. Very often children perceive incumbents' decision regarding ownership and management transfer as unfair. Some believe to be under-rewarded, others over-rewarded. This paper deals with the consequences of injustice perceived by descendants in succession, on the family firm. Findings suggest that not only the family relations suffer but that the family firm becomes target of so called injustice reduction mechanisms, behaviors of descendants designed to restore justice, that have predominantly detrimental effects on the business. Based on survey responses of 1'258 respondents I quantitatively investigate the occurrence of these injustice reduction mechanisms. Underrewarded descendants are expected to feel anger and envy and show behaviors such as less work effort and shirking, free-riding, resistance to change, or legal-claiming. Contrary, perceived injustice is expected to lead the over-rewarded to feel guilty and to result in the following behaviors: more work effort, less satisfaction, salary increase for the under-rewarded and a toleration of less work quality of the under-rewarded. I further test moderating effects of family cohesion. The paper aims to contribute to family business succession, governance and organizational justice literature.
\end{abstract}

\section{Keywords}

Family firm; succession; organizational justice; injustice reduction mechanisms; governance 


\section{INTRODUCTION}

Family-internal succession is a distributional process in which incumbents allocate the family firm, i.e. ownership and management of the firm, to their descendants. They must choose which of their children follow in their footsteps. One main goal of incumbents is that succession is perceived as fair by their descendants to prevent conflict and to enable a smooth succession (Dyer, 1986, Kidwell, Kellermanns, \& Eddleston, 2012; Taylor \& Norris, 2000). However, this objective is often not achieved and the allocation decision results in perceived injustice. Some descendants might think that they did not receive what they deserve and consider themselves as under-rewarded. For instance, a daughter believes that her father should divide ownership equally between her and her siblings but her father then bequeaths the whole ownership stake to the one of the siblings who at the same times takes over the management of the firm. The daughter feels discriminated as she believes that a father should treat his children equally. Or, the son who succeeds in management and is convinced to receive the majority of the shares in the firm learns that the mother allocated ownership equally to her children. The son believes that this is not fair, as he is contributing more to the success of the firm than his siblings. These descendants will perceive the decisions of the incumbents as unfair and feel under-rewarded. Contrary, there will be also descendants who do not believe to be under- but over-rewarded. For example, it might be that a descendant considers an equal division of ownership as fair, but then learns that he or she has been exclusively bequeathed with family firm ownership (Taylor \& Norris, 2000). Or, siblings not working for the company receive an ownership stake and thereby feel over-rewarded towards their siblings working in the firm. These examples show that the allocation decision of incumbents might at the same time produce a situation in which some descendants feel under- and others over-rewarded. Both, the under- and the over-rewarded descendent perceive injustice. This paper investigates the consequences of injustice perceived by family members working in the family business. 
Family business researchers have recognized that justice is an important aspect in family firm succession. It has been discussed that a common understanding of what is just is a key factor for a smooth transition (Dyer, 1986; Le Breton-Miller \& Steier, 2004; Morris, Williams, Allen, \& Avila, 1997; Taylor \& Norris, 2000; Van der Heyden, Blondel, \& Carlock, 2005), as otherwise feelings of injustice create conflict and rivalry between descendants that endanger the survival of the family firm (Ayres, 1990; Baldridge \& Schulze, 1999; Dyer \& Handler, 1994; Friedman, 1991; Kidwell et al., 2012; Taylor \& Norris, 2000; Van der Heyden et al., 2005). Family business governance scholars have indicated that perceived injustice might result in moral hazardous behavior and thereby create agency costs (Baldridge \& Schulze, 1999; Lubatkin, Yan, \& Schulze, 2007). However, a deeper conceptual discussion of perceived injustice in family firm as well as quantitative empirical investigations of its consequences have been lacking so far. That led Gagné, Sharma, \& De Massis (2014) to the conclusion that in family business research "the justice stream is virtually dry". They suggest to use findings of organizational behavior literature to enlighten the role of perceived injustice in family firms. Following their call this paper investigates the consequences of injustice perceived in family firm succession drawing from organizational justice research. "Injustice is hurtful to individuals and harmful to organizations" (Russell Cropanzano, Bowen, \& Gilliland, 2007: 34) and therefore organizational justice as part of the organizational behavior research stream investigates what people believe to be just in the workplace (Colquitt, Conlon, Wesson, Porter, \& Ng, 2001; Greenberg, 1990; Greenberg, 1990). Organizational justice researchers have investigated behaviors that people who perceive injustice apply in the work place and proved that people who perceive a situation as unjust will change their behavior in order to restore justice. The theoretical foundation of these so called injustice reduction mechanisms lies in the definition of injustice presented in the seminal work of Adams (1965). 
In building the hypotheses I draw from these findings of organizational justice research. I intend to answer the question whether some of the injustice reduction mechanisms that were established to be undertaken by under- or over-rewarded employees will also apply in the family business succession context. I thereby test whether family cohesion is able to moderate the relationship between perceived injustice and injustice reduction mechanisms.

The paper therewith intends to contribute to three research streams. First, it adds to family business succession research in empirically investigating whether injustice perceived in succession will have consequences for the business post succession as family members engage in injustice reduction mechanisms addressed at the firm to reduce injustice. I thereby would like to again raise the awareness that succession decisions cannot be regarded as isolated phenomenon but have profound and enduring effects on the family firm. I further address the role of family cohesion in situations of perceived injustice and will answer the question whether it can mitigate its effects. Second, I intend to contribute to family business governance research in offering empirical data to the hypothesis that, besides altruism, an important source of moral hazardous behavior and adverse selection is perceived injustice in succession (Baldridge \& Schulze, 1999; Lubatkin, Yan, et al., 2007). Further, as I expect the over-rewarded descendant to work more I believe to show that perceived injustice has not only detrimental but also beneficial effects for the company.

Third, the paper adds to organizational justice theory in extending its findings to the family business context. As most firms are family firms it is important to investigate the ramifications of family members' behavior on the firm in the event of perceived injustice in succession. I thereby extent the focus in three ways. First, I look at behaviors of the under- and the over-rewarded. Detrimental behaviors of the latter are generally neglected by organizational justice theory. I believe that in the family business succession context such behaviors gain importance as the overrewarded is typically the successor of the firm and his or her feelings and behaviors will 
correspondingly determine firm decisions. Second, I look at justice perceptions that are generated by incidents outside the firm (or in the intersect of the family and the firm) and investigate consequences within the firm. Third, the paper's focus is not restricted to the exchange situation of the dyadic relationship (incumbent - descendant) but investigates how perceived injustice is reciprocated outside this relationship, i.e. to the family firm. In terms of social exchange theory (see e.g. Blau, 2009; Ekeh, 1974; Homans, 1958, 1961; Thibaut \& Kelley, 1959) we deal with an indirect or generalized form of social exchange in which perceived injustice results in behaviors that are not directed to the party causing the pain but to third parties not directly involved in the exchange situation (Bosse, Phillips, \& Harrison, 2009; Ekeh 1974; Wade-Benzoni, 2002).

In short, this paper will provide for empirical results on the effects of perceived injustice in family firm succession. This is helpful for theory to further address the consequences of perceived injustice in family firm succession but will also raise awareness in people dealing with family firm succession in practice to integrate possible effects of injustice perceived by descendants in succession planning.

\section{THEORETICAL BACKGROUND}

\section{Three Different Types of Justice}

Social interaction always implies the exchange of economic and non-economic resources (Leventhal, 1980). In these exchanges the parties distribute resources to each other. Distributions imply decisions about to whom resources are allocated and in what way such resources are divided between possible recipients. As people aim to achieve just allocations, justice forms part of every social interaction. Justice theory now deals with the question of justice in two ways. First, in a normative approach scholars try to answer the question of how goods should be distributed to achieve an ideal state. Others, like this study, focus on what distributions people actually perceive as fair and what they do if they consider situations as unfair. In searching for 
answers regarding what distributions are perceived as fair by the people, justice theory first focused on the outcome of the distribution (distributional justice) (Adams \& Jacobsen, 1964; Cropanzano, Prehar, \& Chen, 2002; Deutsch, 1975; Homans, 1958). It was recognized that there are multiple justice principles at hand according to which the outcome of an allocation can be determined, e.g. equality, equity, seniority, "first come first served" etc. What determines which justice principle is appropriate is first the context of the decision (Leventhal, 1980). It was found that in contexts where interpersonal relations and group solidarity are the primary concern the equality rule prevails (Deutsch, 1975; Drake \& Lawrence, 2000; Leventhal, 1980; Leventhal \& Anderson, 1970), whereas in the business context goods are allocated based on merit to those who are able to use them in the most efficient and effective way (Baldridge \& Schulze, 1999; Deutsch, 1975; Walzer, 1983). But not only the context but also culture, personality traits and the type of resources to be allocated will influence the election of a justice principle (Carney, 2005; Meindl, 1989; Tornblom \& Foa, 1983). So, when distributing estate assets to descendants, Western societies prefer equality transfers while other cultures consider the justice principle of primogeniture as appropriate. Males are more inclined than females to apply the justice principle of merit. And grades are awarded based on merit, while social welfare is given to the ones in need. These examples show that distributional justice is a relative concept.

In a further step, research understood that people assess the fairness of an allocation not based on the outcome alone, but that they evaluate in their fairness judgment also the process of the allocation decision (Leventhal, 1980; Thibaut \& Walker, 1978; Walker, Lind, \& Thibaut, 1979). Scholars determined procedural elements that influence peoples' fairness appraisal, especially in a context where they have limited own decision power (i.e. legal process). Initially numbered among the elements of procedural justice it was later recognized that treating people in a fair and respectful manner constitutes a separate third type of justice, besides distributional and 
procedural justice, called interactional justice (Barclay, Skarlicki, \& Pugh, 2005; Bies, 2005;

Cropanzano, Prehar, \& Chen, 2002). Due to this separation, more formal elements, such as consistency of the justice principle chosen in allocation processes (Barclay et al., 2005; CohenCharash \& Spector, 2001; Leventhal, 1980) are discussed within the concept of procedural justice, and more social elements within the concept of interactional justice.

Family-internal succession is an allocation process and accordingly all three types of justice will shape justice perceptions of the family members. First, distributional justice principles decide about how ownership and management of the company are passed on to the next generation. Distributional justice principles that suggest themselves are equity, equality, need or also the principle of primogeniture (first-born). Culture and personality of the incumbent will decide which justice principle will be applied (Ayres, 1990; Baldridge \& Schulze, 1999; Deutsch, 1975; Fondacaro, Jackson, \& Luescher, 2002; Friedman, 1991; Leventhal, 1980; Van der Heyden et al., 2005). Besides distributional justice also procedural and interactional justice will play a pivotal role in succession. Succession processes are quite different. Some succession processes take years as the transfer of ownership and management from one generation to the next is executed sequentially. Others happen unexpectedly and at short notice following a sudden decease of the incumbent. Procedural elements, e.g. a will or contract of inheritance, having a say in the process etc. will in any procedure influence justice perceptions of family members. Further, interactional justice elements, i.e. understanding and respectful treatment, will be key as successions on the one hand are likely to reopen old wounds (Lansberg, 1988) and on the other hand imply drastic changes in professional and personal life of family members.

In sum, distributional, procedural and interactional justice will shape fairness perceptions of the parties involved in family-internal succession of the family business. Although I consider all types of justice as pivotal, the study is limited to an empirical survey on consequences of 
perceived injustice regarding the outcome of the allocation (distributional justice) and thereby focuses on the two justice principles of equity and equality as there is a tension between these two justice principles in Western societies (Rosenblatt, de Mik, Anderson, \& Johnson, 1985).

\section{Perceived Injustice}

With regard to distributional justice, people consider an allocation as unfair if they do not receive the outcome they feel entitled to. Injustice is a perceived violation of entitlement (Adams, 1965; Mikula, 1993). As mentioned, distributional justice is a relative concept and depends on culture, context, resource and individual. The feelings of entitlement base hence on an individual understanding of what is just in a certain situation. Correspondingly injustice is "perceived" by an individual and not an objectively determinable consequence of a distribution. This relativity of the

justice concept is the reason and primary source of perceived injustice and conflict. Because of the relativity of the justice concept it is highly likely that at least one person to an allocation has a divergent view on how the allocation should be effected.

In our context of distributional justice in family firm succession, it could be that the incumbent considers an allocation based on merit as fair whereas descendants would perceive a transfer of the business according to the justice principle of equality is just. Perceived injustice is therewith generated by conflicting justice perceptions of the parties involved.

\section{Consequences of Perceived Injustice}

Perceived injustice has several consequences. First, perceived injustice will result in emotions and such emotions motivate a change in the behavior of people that is aimed to reduce injustice (Adams, 1965; Barclay et al., 2005; Mikula, Scherer, \& Athenstaedt, 1998; Weiss, Suckow, \& Cropanzano, 1999). Behavioral consequences are summarized in the term injustice reduction mechanisms (Adams, 1965; Barclay et al., 2005; Mikula, Scherer, \& Athenstaedt, 1998; Weiss, Suckow, \& Cropanzano, 1999). Hereinafter, I will discuss the theoretical 
foundation of injustice reduction mechanisms in general and then offer hypotheses regarding the injustice reduction mechanisms resulting from perceived injustice in family firm succession.

\section{Injustice Reduction Mechanisms in General}

The seminal work of Adams (1965) provides for the conceptual basis of injustice reduction mechanisms. According to Adams, exchange situations, or distributions, are considered as fair if parties believe that the outcome received from the exchange corresponds to the input given into the exchange (Adams, 1965; Homans, 1961). Individuals will thereby assess own input and outcome and the input and outcome of the other party to the exchange. The latter hence serve as a reference values (Festinger, 1954). As the amount of inputs and outcomes of people are different, people consider a situation to be fair if they proportionally receive the same and hence the following equation can be made (Adams, 1965):

$$
\frac{\text { Input }_{1}}{\text { Outcome }_{1}}=\frac{\text { Input }_{2}}{\text { Outcome }_{2}}
$$

For example, it is considered as fair if someone who works more receives a higher salary. Here a bigger input (work) leads to a higher outcome (salary). People who work less and receive a lower salary will not consider the situation as unfair. In contrast, if such equation cannot be made, the situation is unfair: the situation in which someone who works less than another person receives a higher salary than such person is regarded as unfair. In unfair situations people are motivated to reduce injustice and Adam's equation gives us the options how they do so (Adams, 1965; Festinger, 1957; Homans, 1961). Namely, in order to restore justice, they can work with each factor of the equation.

The under-rewarded person has the following options:

1. Reduce own input

2. Increase own outcome

3. Increase input of other 
4. Reduce outcome of other

Like a mirror image of the under-rewarded person, the over-rewarded has the following options to retrieve justice:

1. Increase own input

2. Reduce own outcome

3. Reduce input of other

4. Increase outcome of other

Based on Adam's equation organizational justice theory empirically established the occurrence of these injustice reduction mechanisms in the workplace (see for an overview Colquitt et al., 2001; Greenberg, 1990). It was shown that the under- and the over-rewarded engage in the named injustice reduction mechanisms, e.g. the under-rewarded was found to revert to workplace sabotage (Ambrose, Seabright, \& Schminke, 2002), workplace deviance (Bennett \& Robinson, 2000), or counterproductive work behavior (Cohen-Charash \& Spector, 2001) to reduce own input and decrease the outcome of the other (i.e. employer), what corresponds to the first and forth injustice reduction mechanism of the under-rewarded named above. Further, it was for instance found that the over-rewarded will show more work effort (Adams \& Jacobsen, 1964; Greenberg, 1988) and therewith increases own input, what corresponds to the first injustice reduction mechanism of the over-rewarded named above.

In the following, I will draw from these findings in organizational justice theory and investigate whether descendants who feel unjustly treated in family firm succession will undertake injustice reduction mechanisms that affect the family firm (Gagné et al., 2014). Thereafter, I will discuss some indirect effects, the moderating role of family cohesion and mediating role of the emotions anger, envy on side of the under-rewarded and guilt on side of the over-rewarded. 


\section{HYPOTHESES DEVELOPMENT}

\section{Injustice Reduction Mechanisms Following Perceived Injustice in Family Firm Succession}

The under-rewarded person as well as the over-rewarded person are said to engage in injustice reduction mechanisms to reduce perceived injustice. The under-rewarded person in the family business succession is the one of the descendants who feels that he or she does not receive what he or she feels entitled to. Contrary, the over-rewarded person is the one of the descendants who feels that he or she receives more than he or she deserves. Hereinafter the injustice reduction mechanisms are elaborated for each, the under-rewarded person and the over-rewarded person, separately:

\section{Injustice Reduction Mechanisms of the Under-Rewarded Descendant}

Less work effort and shirking (reduce own input). Organizational justice literature has established that there is a relation between peoples' job performance and their perception of fairness (Dittrich \& Carrell, 1979; Janssen, 2001; Masterson, Lewis, Goldman, \& Taylor, 2000; Zhang, Lepine, Buckman, \& Wei, 2014). Job performers evaluate the ratio between efforts spend and rewards received at work (Janssen, 2001) and adjust their behavior if they consider the relationship as unfair. It was established that work efforts are dependent on the exchange relationship with the organization (Zhang et al., 2014). This research confirms Adam's (1965) statement that justice will work as an attractor and that people will change their behavior to reduce injustice. Less work effort is a reduction of input undertaken by the job performer to restore a proportional relation to the outcome received.

I suggest that family members who work in the family firm and feel unjustly treated in succession will change their work behavior. Disappointed descendants will direct their feelings against the family firm and will reduce their work effort or shirk. Through the reduction of work effort by maintaining their position and salary disappointed descendants are able to restore such 
relationship between input and outcome that is according to their view a just one. Same applies to shirking. While work effort is more connected with employees' working attitude in general, shirking comprises rather the willingness to take over new tasks and responsibilities. Shirking is a phenomenon known and extensively discussed in agency theory (Jensen \& Meckling, 1976;

Walsh \& Seward, 1990) and integrated in family business governance literature (Chrisman, Chua, \& Litz, 2004; Schulze, Lubatkin, \& Dino, 2002; Schulze, Lubatkin, Dino, \& Buchholtz, 2001a). Dealing with consequences of the separation of ownership and management agency theory considers shirking as a behavior pattern exhibited by managers that results from the fact that they have interests and risk-exposures different from owners. In order to achieve their goals managers are said to act opportunistically and shirk in the event that they personally do not profit from fulfilling their responsibilities or tasks. This paper suggests that the source of shirking, as well as of less work effort, of family members working in the family firm (not only managers) is perceived injustice. Therefore, the following hypotheses are made:

Hypothesis 1a. Descendants who feel under-rewarded in succession and work in the family business are likely to reduce work effort.

Hypothesis 1b. Descendants who feel under-rewarded in succession and work in the family business are likely to shirk.

Free-riding/Consumption of company resources (increase own outcome). Organizational justice literature has established that perceived injustice of employees leads to employee theft (Greenberg, 1990). Greenberg's study was effected in a company that was, because of a loss of large manufacturing contracts, forced to cut wages by $15 \%$. After the wage cut employees reported feeling underpaid and stole over twice as much as they did when they felt equitably paid. Greenberg reflects that these acts of theft can be interpreted as "unofficial transfers of outcomes from the employer to the employee" (p. 566). It allows employees to increase their outcome without 
increasing their input and therewith restore the, in their view, just relation between their input and outcome. In the study of Greenberg, perceived injustice led to illegal behavior. A milder form of theft is free-riding. Free-riding means that someone consumes resources without contributing in return and is like shirking a construct often discussed in agency theory and applied to the family business context (Baldridge \& Schulze, 1999; Jensen \& Meckling, 1976; Lubatkin, Ling, \& Schulze, 2007; Schulze, Lubatkin, \& Dino, 2003; Schulze et al., 2001; W. S. Schulze, Lubatkin, \& Dino, 2003; Schulze, Lubatkin, Dino, \& Buchholtz, 2001). Family members who work in the firm and feel unjustly treated have the opportunity to restore justice by an increased consumption of the firms' resources. Hence, the following hypothesis is made:

Hypothesis 2. Descendants who feel under-rewarded in succession and work in the family business will free-ride.

Resistance to change (increase input of other). Employees who feel treated fairly will support organizational change. Contrary, perceived injustice will lead to resistance to change (Folger \& Skarlicki, 1999). Organizational change requires the support of the employees. Employees might face great uncertainty in organizational change and this stage is therefore connected to a heightened sensibility of the employees. Their support for change is only achieved in the event that they trust the leadership of the company and their working environment. Such trust is shaken in the event that employees feel unjustly treated, and consequently they will resist change. Resistance to change implies that the leaders of the company have to increase their efforts and work harder to convince employees to undertake the envisaged change. With regard to Adam's equation (1965) one can say, that perceived injustice results in behavior of under-rewarded employees that induces the over-rewarded supervisors to increase their input. Correspondingly resistance to change is an injustice reduction mechanisms aimed to increase the input of the overrewarded. 
In family firm succession, support for change is pivotal as succession alters so many areas of family and business life. Succession entails changes in the relationships of family members, fathers and mothers retire, other family members take over new functions in ownership or management. Often, succession is a reason for long-term non-family employees to leave the company what implies further changes in the staff. Changes also affect the strategy of the business as successor managers commonly introduce new products, services, processes such as IT solutions, or enter new geographical markets (Sharma, Chrisman, \& Chua, 1997). Hence, resistance to change of employed family members is likely to be a stumbling block for successful succession. Family members who perceive injustice following a succession decision will exhibit such behavior to increase the input of other family members and therewith to restore justice. Correspondingly, the following hypothesis is made:

Hypothesis 3. Descendants who feel under-rewarded in succession and work in the family business are likely to resist change (e.g. new products).

Legal claiming (decrease outcome of other). Organizational injustice was found to be a predictor of employee legal-claiming behavior (Goldman, 2003). It was detected that underrewarded employees engage in legal-claiming as retaliation for perceived unfairness (Goldman, 2003; Lind, Greenberg, Scott, \& Welchans, 2000). In the language of Adams (1965) legal-claiming can be qualified as an attempt of the under-rewarded to reduce the outcome of the other and increase at the same time own outcome.

In practice, there are abundant legal claims following inheritance disputes. That legalclaiming constitutes an attempt to reduce injustice and therefore can be considered as injustice reduction mechanism offers an accurate explanation for the myriad of legal claims of underrewarded descendants also in family firm succession. It is highly likely that perceived injustice in succession leads to increased legal claiming of under-rewarded family members with the goal to 
decrease the outcome of the over-rewarded descendant. The following hypothesis is therefore made:

Hypothesis 4. Descendants who feel under-rewarded in succession are likely to engage in legal-claiming.

\section{Injustice Reduction Mechanisms of the Over-Rewarded Descendant}

More work effort (increase own input). As stated above, organizational justice researchers established that employees who feel unjustly treated will revert to diverse behaviors that are detrimental to the business. However, perceived injustice is also able to evoke behavior that is beneficial for the company in the event employees consider themselves over-rewarded. So, it was shown that employees who think that they are overpaid will increase relevant input. For instance Adams \& Jacobsen (1964) gave students a proof-reading task. The students who were made to believe that they are not experienced enough for the job and correspondingly overpaid produced significantly better quality work than other students who thought that their experience was adequate. The same injustice reduction mechanisms were observed in the event non-monetary outcomes were manipulated. Greenberg (1988) observed that employees who were temporarily moved to higher-status offices than their position actually warranted, increased their performance.

These reactions can be qualified as an attempt of the employees to increase their input after having received more "outcome" than they consider to deserve. With increased work effort employees try to restore a just proportion between their input and outcome. Same will apply if family members perceive to be over-rewarded in family firm succession. They will exhibit increased work efforts to show that they are worth the allocated resources and therewith reduce injustice. Hence the following hypothesis is made:

Hypothesis 5. Descendants who feel over-rewarded in succession are likely to increase work effort. 
Less job satisfaction (reduce own outcome). Justice was found to be a predictor for work satisfaction (Cohen-Charash \& Spector, 2001; Colquitt \& George, 2011; McFarlin \& Sweeney, 1992). Job satisfaction is in the exchange relation with the employer an outcome, such as salary. According to Adams' equation, if someone feels over-rewarded he or she is likely to reduce own outcome. In the family business context, this means that perceived injustice in the succession might be a trigger for reduced job satisfaction of the over-rewarded descendant. Hence, the following hypothesis is made:

Hypothesis 6. Descendants who feel over-rewarded in succession are likely to have less job satisfaction.

Salary increase to under-rewarded family member (increase outcome of other). A possible injustice reduction mechanism of the over-rewarded is to increase the outcome of the under-rewarded. This injustice reduction mechanism has not been discussed to a great extent in organizational justice literature as detrimental injustice reduction mechanisms of the underrewarded - and not the over-rewarded - have been more in the center of attention. It has been also suggested that over-rewarded peoples' threshold to react to perceived injustice is higher than the one of under-rewarded people (Adams, 1963). However, injustice reduction mechanisms undertaken by the over-rewarded may be detrimental for the firm to the same (or even bigger) extent. In family firms, over-rewarded family members regularly have key positions in the firm. A possible injustice reduction mechanism of the over-rewarded successor is to raise the salary of the under-rewarded family member employed in the firm. With such salary increase, the over-rewarded is able to increase the outcome of the under-rewarded and to recompense the under-rewarded for the injustice experienced in succession. Salary increases will be made by the over-rewarded even though he or she has no decision power and therefore did not cause injustice. Hence, the following hypothesis is made: 
Hypothesis 7. Descendants who feel over-rewarded in succession are likely to give pay increases to under-rewarded descendants.

Toleration of less work effort (reduce input of other). As mentioned before, job performance of under-rewarded employees is likely to decline because of perceived injustice (Dittrich \& Carrell, 1979; Janssen, 2001; Masterson et al., 2000; Zhang et al., 2014). I stated that less work effort and shirking could be considered as attempts of the under-rewarded person to reduce input. In general, such behavior would provoke counter-measures of the employer. However, in the event such employer is a family member feeling over-rewarded he or she is tempted to tolerate the change in the work attitude of the under-rewarded descendant. Such toleration constitutes an approval of the input reduction of the under-rewarded person. Hence the following hypothesis is made:

Hypothesis 8. Descendants who feel over-rewarded in succession are likely to tolerate less work effort of the underrewarded.

\section{Moderating Effects of Family Cohesion}

Family cohesion is a construct that reflects the quality of the relationship between the family members (Dyer \& Handler, 1994; Fondacaro et al., 2002; Journal, Wennberg, Wiklund, \& Nordqvist, 2011; Lansberg \& Astrachan, 1994; Wiklund, Nordqvist, Hellerstedt, \& Bird, 2013). I suggest that high family cohesion will influence how family members react to perceived injustice. High family cohesion will weaken the relationship between perceived injustice and injustice reduction mechanisms undertaken by the under-rewarded. Strong family relations will lead to a higher level of empathy and will inhibit descendants from assuming bad intent and parental favoritism (Friedman, 1991; Lansberg \& Astrachan, 1994). Under-rewarded descendants therefore will try to understand the reasoning of the incumbent. Moreover, if family cohesion is high family members care for each other and protect each other from harm. Good relationships to 
other family members will correspondingly keep the under-rewarded from engaging in injustice reduction mechanisms directed against the company or other family members. Hence, the following hypothesis is made:

Hypothesis 9a. High family cohesion will reduce the positive relationship between perceived injustice and injustice reduction mechanisms undertaken by the under-rewarded.

Contrary, I assume that high family cohesion will increase the relationship between perceived injustice and injustice reduction mechanisms on the side of the over-rewarded. In families with high cohesion family members will care for each other and act loyal towards each other (Lansberg \& Astrachan, 1994). Family members that feel close will interact regularly and share joys and burdens. They will know each other's frame of mind. Thus, over-rewarded family members of families with high cohesion will know about the pain the under-rewarded descendant feels following a discrimination and will suffer with them. Because of this closeness I believe that over-rewarded descendants of families with high family cohesion are motivated to a higher degree than over-rewarded descendants of families with low family cohesion to reduce injustice. Hence, the following hypothesis is made:

Hypothesis $9 b$. High family cohesion will increase the positive relationship between perceived injustice and injustice reduction mechanisms undertaken by the over-rewarded.

In sum, I predict that high family cohesion will have the opposite effect on the over- and the under-rewarded person. Under-rewarded descendants from families with high cohesion are expected to engage in injustice reduction mechanisms to a lesser extent. Contrary, over-rewarded descendants from families with high cohesion are expected to increase injustice reduction mechanisms.

\section{Mediating Effects of Emotions}


Organizational justice research has established that besides behavioral consequences, perceived injustice has an impact on the feelings of the people.

Emotions of the under-rewarded descendant. The under-rewarded person is said to feel angry (Adams, 1965; Barclay et al., 2005; Kidwell et al., 2012; Mikula, 1993; Taylor \& Norris, 2000). Anger results from perceived injustice and will result in retaliation behavior (Barclay et al., 2005; Mikula et al., 1998; Weiss et al., 1999). Anger, as out-ward focused emotion, signifies that the angry person blames another to be responsible for the outcome and correspondingly retaliation behavior resulting from outward-focused emotions is supposed to be directed against the perpetrator (Barclay et al., 2005). Further, perceived injustice provokes another feeling that is not directed against the perpetrator but to the one who is considered to be favored. This is the feeling of envy. As people evaluate their situation in comparison with others (Festinger, 1954), envy typically occurs if a person lacks another's possession and desires it (Parrot \& Smith 1993). Sibling relationships are generally prone to provoke envy (Yoshimura, 2010), as siblings are each other's reference group with regard to parental allocations. So, I propose that in the context of family firm succession the under-rewarded descendant will feel anger and envy and that these feelings mediate the relationship between perceived injustice and injustice reduction mechanisms undertaken by the under-rewarded. Hence,

Hypothesis 10a. The relationship between perceived injustice and injustice reduction mechanisms is mediated by the feeling of anger on the side of the under-rewarded descendant.

Hypothesis 10b. The relationship between perceived injustice and injustice reduction mechanisms is mediated by the feeling of envy on the side of the under-rewarded descendant.

Emotions of the over-rewarded descendant. The over-rewarded person is expected to feel guilty (Adams, 1965; Barclay et al., 2005). Generally, guilt involves that the person feels responsible for the outcome (Smith, Haynes, Lazarus, \& Pope, 1993; Weiss et al., 1999), what 
would be less the case in a succession decision taken by the incumbent. However, it has been advanced that guilt can also be generated in the absence of any own wrong-doing (Baumeister, Stillwell, \& Heatherton, 1994). For instance, drawing from the known phenomena of survivor guilt (Lifton, 1967), justice researchers have established that in connection with perceived injustice people can feel guilty because of the mere perception that their rewards are larger than the rewards of someone else (Baumeister et al., 1994). Guilt however requires that the over-rewarded feels connected to the under-rewarded to some extent, as such guilt is said to have an interpersonal origin (Baumeister et al., 1994). Baumeister et al. (1994) make the example that receiving extra change from a pay telephone is unlikely to result in guilt, so the over-rewarded will only feel guilty if there is a salient other person that is under-rewarded. Guilt is associated with prosocial effects, such as altruistic behavior, reparation payments, confessions or apologies (Baumeister et al., 1994) as well as with antisocial effects, such as avoidance and withdrawal (Barclay et al., 2005; Baumeister et al., 1994). Hence, I suppose that guilt will mediate the relationship between perceived injustice and injustice reduction mechanisms undertaken by the over-rewarded. Correspondingly:

Hypothesis 10c. The relationship between perceived injustice and injustice reduction mechanisms is mediated by the feeling of guilt on the side of the over-rewarded descendant.

\section{METHODOLOGY}

\section{Sample and Data Collection}

To empirically test whether people engage in injustice reduction mechanisms following perceived injustice in family firm succession, I included corresponding scenarios in a survey about succession that was sent out to managers of $38^{`} 049$ small- and medium-sized enterprises (SMEs). SMEs are firms with less than 250 employees (additionally, a corresponding if-condition was included in the in Stata commands). 
There were two versions of the survey, one version contained the over-rewarded scenario and the other version contained the under-rewarded scenario (see below). The two versions were randomly sent out to the respondent SMEs. The goal thereby was to expose two groups to a different scenario but that these groups are alike in all other aspects, or at least do not systematically differ (Punch \& Oancea, 2014).

The distribution of the survey participants deviates somewhat from the sector and size structure of the overall Swiss SME landscape reflected in the most recent statistics on corporate structure (STATENT) of the Swiss Federal Statistical Office (SFSO) dating from 2013. Construction and industrial firms are overrepresented in the survey, while SMEs from various service sectors are underrepresented. In addition, micro firms with fewer than ten full-time equivalents (FTEs) are underrepresented in the survey compared to their actual frequency in Switzerland. ${ }^{1}$

Data collection was effected in January and February 2016 and achieved a total of 1'528 survey responses. This corresponds to a response rate of $4.02 \%$. The low response rate is ascribed to the fact that the questionnaire was rather long.

As dependent and independent variables stem from the same respondents and the same survey, therefore, common method variance has to be addressed. To do so two post-hoc tests were effected: Harman's single factor test and the marker variable test (Lindell \& Whitney, 2001) To conduct the Harman single factor test, I entered all variables of Models 3 and 6 into an exploratory factor analysis using principal component factor analysis (Podsakoff, MacKenzie, Lee, \& Podsakoff, 2003). For the under-rewarded scenario (Model 3), five factors have an eigenvalue greater than one, all accounting for $61.27 \%$ of the total variance. The first factor explains only $22.32 \%$ of the total variance what indicates that no single factor accounts for the majority of the variance.

\footnotetext{
${ }^{1}$ The following sectors were excluded from the analysis: agriculture/forestry, energy/water supply, finance/insurance, public administration.
} 
Regarding the over-rewarded scenario (Model 6), four factors have an eigenvalue greater than one, all accounting for $52.84 \%$ of the total variance. The first factor explains only $18.8 \%$ of the total variance what indicates that no single factor accounts for the majority of the variance. Further, I conducted the marker variable test (Lindell \& Whitney, 2001) investigating the correlation (including all other variables) between the dependent variable (injustice reduction mechanisms of under- and over-rewarded, combined) and another variable that theoretically should be uncorrelated with the dependent variables, called marker variable (Homburg, Klarmann, \& Schmitt, 2010). This variable is then used to correct the correlation matrix for common method bias. I assessed the correlation between the marker variable "existence of governance instruments" and the injustice reduction mechanisms undertaken by the under-rewarded $(\mathrm{r}=-0.0264)$, respectively by the over-rewarded $(r=-0.0292)$. This predictor has insignificant correlations with the dependent variables. Overall, the statistical significance and correlations do not change, which provides further evidence that common method bias is not present (Van Doorn \& Verhoef, 2008).

\section{Measures}

Independent variables. The independent variable is the likelihood of perceived injustice. Perceived injustice was provoked in confronting respondents either with the under- or the overrewarded scenario. Respondents were then asked: "How likely do you perceive this decision as unjust?". They could answer on a seven-point scale that ranged from "not likely at all" to "very likely".

In the scenarios, the respondents were put in the position of a descendant of the family business. They were informed that their father allocated ownership of the family firm according to the equity principle to the one of the descendants who also takes over the management. Further, it was written that such allocation contradicted their sense of justice, as according to their perception a transfer in compliance with the equality principle would have been just where 
ownership of the business is handed over equally to all descendants. In the scenarios, descendants and incumbent have therefore divergent perceptions of justice.

The wording for the scenario of the under-rewarded was:

"Assume the following scenario: Your family has a family business. Your father is soleowner and manager of the business. You have a twin-brother. Your twin-brother has studied business management, has work experience outside the family business and is since a couple of years in the family business. He will succeed your father in managing the family business. Yourself, you are employed in the family business as case-handler with a normal salary. You are of the opinion that the shares in the company (ownership) should be handed over equally to you and your brother. After the decease of your father you learn however that your father left all the shares in the company (100\%) to your brother alone."

The wording for the scenario of the over-rewarded was:

"Assume the following scenario: Your family has a family business. Your father is soleowner and manager of the business. You have studied business management, have work experience outside the family business and are since a couple of years in the family business. You will succeed your father in managing the family business. You have a twinbrother. Your twin is employed in the family business as case-handler with a normal salary. You are of the opinion that the shares in the company (ownership) should be handed over equally to you and your brother. After the decease of your father you learn however that your father left all the shares in the company (100\%) to you alone."

To exclude the appropriability of the justice principle of need or primogeniture/seniority, I included that the siblings are twins, and that the under-rewarded receives a normal salary.

Dependent variables. The dependent variables are the injustice reduction mechanisms. Respondents were asked the following questions and could respond to the questions on a sevenpoint scale that ranged from "not likely at all" to "very likely". To learn whether respondents engage in injustice reduction mechanisms, they were asked in the under-rewarded scenario: "How likely do you show less work effort?" and "How likely do you shirk from new tasks?" to learn whether under-rewarded persons show less work effort and engage in shirking, which is equivalent to a reduction of input. In order to figure out whether under-rewarded persons will free-ride which is equivalent to an increase of outcome respondents were asked: "How likely do 
you use available company resources more excessively?". To detect whether there are injustice reduction mechanisms that consist in an increase of the input of other respondents were asked: "Your brother wants to introduce a new product. How likely do you oppose?". And lastly, in order to find out about the motivation to reduce the outcome of the other respondents were asked: "How likely to you file a legal suit to receive the same number of shares in the company as your brother?". When I tested the indirect effects (moderating effect of family cohesion and mediating effects of anger and envy) I created a combined variable of all the five items asked. For that purpose, I created a variable that indicated whether the items were answered and another variable representing the sum of the five items that measured the likelihood of the injustice reduction mechanisms. I then divided the latter variable through the former, under the condition that more than two items were answered. Cronbach's alpha reaches 0.8254 and average likelihood of the injustice reduction mechanism undertaken by the under-rewarded is 3.31 .

To learn whether respondents engage in injustice reduction mechanisms, they were asked in the over-rewarded scenario: "How likely do you show more work effort now?" in order to learn whether over-rewarded descendants will increase own input. To detect whether own outcome will decrease over-rewarded descendants were asked: "How likely do you have less job satisfaction?". To see whether over-rewarded persons increase the outcome of other the question was: "Your brother demands a pay increase. How likely do you approve the increase?". And lastly, to investigate whether they reduce input of other and tolerate less work effort overrewarded persons were asked: "Your brother works with less work quality now. How likely do you tolerate this behavior?". When I tested the indirect effects (moderating effect of family cohesion and mediating effects of guilt) I created a combined variable of all the items asked. For that purpose, I created a variable that indicated whether the items were answered and another variable representing the sum of the four items that measured the likelihood of the injustice 
reduction mechanisms. I then divided the latter variable through the former, under the condition that more than two items were answered. The average likelihood of the injustice reduction mechanism undertaken by the over-rewarded is 3.65. Cronbach's alpha reaches 0.5240 and therefore a factor analysis (principal component) was effected what showed that the item "more work effort" has an eigenvalue greater than 1 and accounts for $42.46 \%$ of the variance.

Control variables. I controlled for the following variables on industry-, firm- and individual level that have been found to be important in prior studies of family business and justice research. Industry. Industry may be a critical factor for the type of successor needed (Le BretonMiller \& Steier, 2004), and hence of the type of succession that is considered as fair. I computed a dummy variable and considered companies active in the secondary sector (manufacturing) being equal to " 0 ", while firms of the tertiary sector (services) were coded as " 1 ". There were no firms of the primary sector.

Firm size. In small firms a separation of ownership and management might be less feasible, hence I controlled for firm size. Size was measured in counting the number of employees. The average number of employees is 27.3 .

Firm age. Respondents were asked in which year their company was founded and such year was deducted from 2016. The average firm age is 43.9 years (1-328 years). For firm age was controlled as respondents from very old firms might be more inclined to the justice principle of equity as in order to survive over a longer period of time companies must deliver above-average performance.

Performance. Performance might influence respondents' justice perceptions. Respondents of companies with very low performance might perceive the company as burden and the scenario intended to evoke preferential treatment might in fact was not perceived as over-rewarding. Performance was measured by taking the average growth rate of the total operating revenues of 
the years 2013-2015. I deducted the revenues of 2013 and 2014 from the revenues 2014 respectively 2015 and divided the result through the revenue of 2013, respectively 2014 to compute the relative average growth rate and then added the two results and divided it by two to calculate the average growth rate. The mean average growth rate is 0.058 .

Region. What is perceived as fair is culturally dependent (Carney, 2005; Meindl, 1989). Accordingly, other cultures will make different justice judgments. For example individualistic countries, as the United States of America, will promote the application of the equity principle (Hofstede, 1984; Meindl, 1989). Contrary, more collectivistic countries are predicted to emphasize the justice principle of equality (Hofstede, 1984; Meindl, 1989). Switzerland comprises different cultures what is reflected by the situation that there are three main languages spoken: German, French, and Italian (a small minority speaks Rhaeto-Romanic). The French and Italian speaking part of Switzerland are often subsumed under the term "Latin Switzerland". The German speaking part is said to have a stronger emphasis on equity (Hofstede, 2016). Hence a dummy variable was coded whereas 0 represents questionnaires sent out in the German language $(76.79 \%)$ and 1 , questionnaires that were sent out in the French and Italian language (23.21\%).

Age of respondent. With age, people might change their justice judgments hence respondents were asked for the year they were born and such was deducted from 2016. The average age of the respondent is 54 years.

Gender. Respondents were asked whether they are male or female as with regard to distributional processes men and women were found to act differently (Cohen-Charash \& Spector, 2001). It was recognized that females are more than males inclined to the justice principle of equality, as their major concern is to maintain the welfare of the group members (Ahl, 2002; Kahn, O’Leary, Krulewitz, \& Lamm, 1980; Leventhal \& Lane, 1970). Hence I coded a dummy variable $(1=$ female $) .0 .1 \%$ of the respondents are women. 


\section{Moderating variable.}

Family cohesion was assessed via four items from the FACES III scale (Olson, 1986, 1991). Respondents could indicate on a seven-point scale within the range: "I strongly disagree - neutral - I completely agree", how they evaluate the following statements: "family ties are very important to us", "family members in our family feel very close", "if the family comes together all family members are present", and "family members support each other" (see also Zellweger et al., 2015). I created a variable that indicated whether the items were answered and another representing the sum of the four items that measured the degree of cohesion. To define mean family cohesion, the latter variable was divided through the former, under the condition that more than two items were answered. Cronbach's alpha reaches 0.916 and average mean cohesion is 5.31 .

\section{Mediating variables.}

Anger. Respondents were asked „How likely is it that this decision makes you angry?“ Respondents could answer the question on a seven-point scale that ranged from "not likely at all" to "very likely".

Envy. Respondents were asked „How likely is it that you envy your brother for the ownership stakes?" Respondents could answer the question on a seven-point scale that ranged from "not likely at all" to "very likely".

Guilt. Respondents were asked „How likely is it that you feel guilty towards your brother?“ Respondents could answer the question on a seven-point scale that ranged from "not likely at all" to "very likely".

\section{Data Analysis}

Descriptive statistics including number of observations, mean, standard deviation, and correlations for all variables used in the regression analysis can be found in Table 1 and Table 2. The tables show acceptable levels of correlation between independent and control variables being 
lower than 0.2 (Hair, Black, Babin, Anderson, \& Tatham, 2006). The Variance Inflation Factors (VIF) values are all below the accepted threshold of 4 (Hair et al., 2006) with the highest VIF amounting (under-rewarded: 0.9897; over-rewarded: 0.9838) indicating that multicollinearity is not a major concern for the study.

\section{insert Table 1 and Table 2 around here}

\section{Analytical Procedures and Results}

To test the hypotheses, I employed simple regressions. Table 3 (Models 1-3) displays the models for the under-rewarded scenario and Table 4 (Models 4-6) for the over-rewarded scenario. For the under-rewarded scenario: Model 1 contains the regressions from the independent variable together with the control variables on the injustice reduction mechanisms individually. Model 2 contains the regressions on the mean of the combined injustice reduction mechanisms including the moderating effect of family cohesion. Model 3 tests mediation effects of anger and envy in establishing the conditions required by Baron \& Kenny (1986). For the over-rewarded scenario: Model 4 contains the regressions from the independent variable together with the control variables on the injustice reduction mechanisms individually. Model 5 contains the regressions on the mean of the combined injustice reduction mechanisms including the moderating effect of family cohesion. Model 6 tests the mediating effect of guilt (Baron \& Kenny, 1986).

insert Table 3 and 4 around here

Under-rewarded. Table 3 shows that perceived injustice significantly increases the likelihood of all injustice reduction mechanisms predicted to be undertaken by the under-rewarded. So perceived injustice will lead to reduced work effort and shirking, hypotheses 1a (Model 1: $\beta=$ $0.410, \mathrm{p}<0.001)$ and hypothesis $1 \mathrm{~b}($ Model 1: $\beta=0.352, \mathrm{p}<0.001)$ are therewith supported. 
Further, it will increase the likelihood of free-riding (consumption of company resources) and resistance to change as well as legal claiming. Correspondingly hypotheses 2 (Model 1: $\beta=0.344$, $\mathrm{p}<0.001$ ), 3 (Model 1: $\beta=0.133, \mathrm{p}<0.01$ ), and 4 (Model 1: $\beta=0.494, \mathrm{p}<0.001$ ) are supported.

Over-rewarded. Table 4 shows that perceived injustice will not increase the likelihood of more work effort, so hypothesis 5 (Model 4: $\beta=0.0621, \mathrm{p}>0.1$ ) is rejected. Contrary, perceived injustice will significantly increase the likelihood of less job satisfaction (Model 4: $\beta=0.288, p<$ 0.001), salary increases towards the under-rewarded sibling (Model 4: $\beta=0.330, p<0.001$ ), and toleration of less work effort (Model 4: $\beta=0.141, \mathrm{p}<0.001$ ). Therewith hypotheses 6,7 , and 8 are supported.

Moderating effects of family cohesion. Models $2(\beta=0.0254, \mathrm{p}>0.1)$ and $5(\beta=-0.0217$, $\mathrm{p}>0.1)$ show that family cohesion has no moderating effect on the relationship between perceived injustice and the performance of injustice reduction mechanisms, so hypotheses 9a and 9b are rejected.

Mediating effects of anger, envy, and guilt. Model 3 indicates a rather clear mediation effect of the feeling of anger, which supports hypothesis 10a. The effect is less clear with regard to the feelings of envy and guilt, but still hypotheses 10b (Model 3) and 10c (Model 6) receive support. In a post hoc analysis it was found that guilt leads to more work effort $(\beta=0.149, p<0.001)$, and correspondingly full mediation of guilt in the relationship between perceived injustice and increased work effort is assumed. Moreover, it was found that family cohesion has a moderating effect on the relationship between guilt and increasing injustice reduction mechanisms $(\beta=-$ $0.0392, \mathrm{p}<0.05)$. Contrary to the argumentation with regard to perceived injustice, high family cohesion combined with guilt will result in decreasing injustice reduction mechanisms on behalf of the over-rewarded. 
Additionally, under-rewarded respondents were asked whether they required a compensation and if yes, who should compensate them, father or brother. $45.33 \%$ of the respondents answered that they require no compensation. Of the other $54.67 \%, 36.13 \%$ wish to receive $100 \%$ of the compensation from the father, $20.07 \%$ wish to receive $100 \%$ of the compensation from the brother and $28.83 \%$ wish to split the compensation between father and brother 50:50. One can draw from these findings that under-rewarded descendants will exhibit injustice reduction mechanisms vis-àvis all parties involved in the allocation, the father - which seems obvious as he is the perturbator - the brother and the family firm, which is less evident as these parties do not directly harm the under-rewarded person.

\section{DISCUSSION}

The paper aims to provide a conceptual and empirical basis for behaviors of family members that result from perceived injustice in family firm succession and that affect the family business. The findings indicate that perceived injustice leads to injustice reduction mechanisms undertaken by the under-rewarded descendant that have alarming negative effects on the family business (less work effort, shirking, free-riding, resistance to change, legal claiming). But not only the underrewarded is motivated to restore justice and thereby harms the firm, also the over-rewarded descendant proved to engage in acts that are detrimental to the firm. Worth particular mention is that the over-rewarded descendant will increase the salary of the under-rewarded family member working in the firm. This proves that perceived injustice will not only result in negative feelings of the family members involved and harm family relationships but are very dangerous for the family firm, a finding that has been neglected so far. Unfortunately, the findings show that family cohesion cannot mitigate the effect what raises the question of how the problem of perceived injustice can be handled. 


\section{Contributions, Future Research, \& Limitations}

The paper contributes to three research streams. First, the paper adds to family business succession research in empirically proving that injustice perceived in succession will have negative consequences for the business post succession as family members engage in injustice reduction mechanisms addressed at the firm. I want to stress that perceived injustice therewith enduringly affects the company and might influence the behavior of family members over generations (WadeBenzoni, 2002). Second, the paper adds to family business governance research in offering another source or motive for moral hazard and adverse selection, two behaviors that, in family firm research, have so far nearly exclusively been discussed in connection with altruism. I believe that perceived injustice more often motivates family members' behavior in family firms than it has been considered so far. Third, the paper contributes to organizational justice research in showing how in family firms, issues that not directly happen in the firm, will nevertheless influence the work environment. In view of the myriad of family firms, and especially the multitude of sibling partnerships in family firms - in which relationship perceived injustice is highly likely (Ward, 1997) - organizational justice researchers have to deal with injustice perceived by family members that affects the family business organization. Family members' behavior will additionally have an influence on non-family employees (e.g. salary increases to under-rewarded descendants but not to non-family members are likely to reduce organizational justice climate in general and organizational citizenship behavior of non-family employees). The paper also draws the attention to detrimental behavior of the over-rewarded, what has been less the focus of organizational justice research so far. Also, the paper demonstrates that behaviors resulting from perceived injustice will not rest in the dyad relationship between the parties to the exchange but will affect other parties (indirect exchange), i.e. the over-rewarded person, or in our context, the family firm (Bosse, Phillips, \& Harrison, 2009; Ekeh 1974; Wade-Benzoni, 2002). Further, the study revealed that 
under-rewarded respondents require a compensation not only from the father $(59.96 \%)$, but also from the brother $(40.04 \%)$.

Future research might be able to more closely investigate the role of the feelings resulting from perceived injustice. Especially, I believe that we will gain more insight in examining the feeling of guilt and its connection to the injustice reduction mechanisms undertaken by the overrewarded (family cohesion might be able to moderate this relation). The over-rewarded has generally the power in family firms and is therewith able to do a lot of damage to the family firm. Also, future research could investigate how family firms can address perceived injustice and mitigate its consequences. Here, elements of procedural and interactional justice will play an important role (e.g. having a say in succession process). Also, violations of other justice principles (need, primogeniture) can be analyzed, and how people from other culture deal with perceived injustice in the family firm context. Very interesting would be to survey whether perceived injustice is passed on to the next generation and what impact that has on the family business. Further, we must define more thoroughly the concepts of perceived injustice and injustice reduction mechanisms in the family business context. These suggestions at the same time reveal the limitations of the present study. The study does not deal with other justice principles or other types of justice. There will be other injustice reduction mechanisms that have not been considered in this study. Also, the data stems from a hypothetical scenario, and therefore lacks verification.

The paper has tried to connect family business and organizational behavior research in showing that the injustice reduction mechanisms found in organizational justice research are also applied by family members who perceive injustice in family firm succession. The combination of these two research streams provides for fertile ground to better understand the influence of the family in the family firm and hopefully is used more frequently in future. 


\section{References}

Adams, J. S. 1963. Toward an understanding of inequity. Journal of Abnormal Psychology, 67(5): 422-436.

Adams, J. S. 1965. Advances in experimental social psychology. In L. Berkowitz (Ed.), Inequity in social exchange: 267-299. New York: Academic Press.

Adams, J. S., \& Jacobsen, P. R. 1964. Effects of wage inequities on work quality, 69(1): 19-25.

Ahl, H. J. 2002. The making of the female entrepreneur - a discourse analysis of research texts on women's entrepreneurship. Jönköping: Jönköping International Business School.

Ambrose, M. L., Seabright, M. A., \& Schminke, M. 2002. Sabotage in the workplace: The role of organizational injustice. Organizational Behavior and Human Decision Processes, 89(1): 947-965.

Ayres, G. R. 1990. Rough family justice: Equity in family business succession planning. Family Business Review, 3(1): 3-22.

Baldridge, D. C., \& Schulze, W. S. 1999. Fairness in family firms: An organizational justice perspective on agency problems. Academy of Management Proceedings, 1: C1-C6.

Barclay, L. J., Skarlicki, D. P., \& Pugh, S. D. 2005. Exploring the role of emotions in injustice perceptions and retaliation. The Journal of Applied Psychology, 90(4): 629-43.

Baron, R. M., \& Kenny, D. A. 1986. The moderator-mediator variable distinction in social psychological research: Conceptual, strategic, and statistical considerations. Journal of Personality and Social Psychology, 51(6): 1173-1182.

Baumeister, R. F., Stillwell, a M., \& Heatherton, T. F. 1994. Guilt: An interpersonal approach. Psychological Bulletin, 115(2): 243-267.

Bennett, R. J., \& Robinson, S. L. 2000. Development of a measure of workplace deviance. Journal of Applied Psychology, 85(3): 349-360.

Bies, R. J. 2005. Are procedural justice and interactional justice conceptually distinct? In J. Greenberg \& J. A. Colquitt (Eds.), Handbook of organizational justice: 85-112. Mahwah, NJ, US: Lawrence Erlbaum Associates, Inc.

Blau, P. 2009. Exchange and Power in Social Life (Thirteenth). New Brunswick, London: Transaction Publishers.

Bosse, D. A., Phillips, R. A., \& Harrison, J. S. 2009. Stakeholders, reciprocity, and firm performance. Strategic Management Journal, 30: 447-456.

Carney, M. 2005. Corporate governance and competitive advantage in family-controlled firms. Entrepreneurship Theory and Practice, 249-265.

Chrisman, J. J., Chua, J. H., \& Litz, R. A. 2004. Comparing the agency costs of family and nonfamily firms: Conceptual Issues and exploratory evidence. Entrepreneurship Theory and Practice, 28(4): 335-354.

Cohen-Charash, Y., \& Spector, P. E. 2001. The role of justice in organizations: A meta-analysis. Organizational Behavior and Human Decision Processes, 86(2): 278-321.

Colquitt, J. A., Conlon, D. E., Wesson, M. J., Porter, C. O., \& Ng, K. Y. 2001. Justice at the millennium: A meta-analytic review of 25 years of organizational justice research. The Journal of Applied Psychology, 86(3): 425-445.

Colquitt, J. A., \& George, G. 2011. Publishing in AMJ_PART 1: Topic choice. Academy of Management Journal, 54(3): 432-435.

Cropanzano, R., Bowen, D. E., \& Gilliland, S. W. 2007. The management of organizational justice. Academy of Management Perspectives, 21(4): 34-48.

Cropanzano, R., Prehar, C. A., \& Chen, P. Y. 2002. Using social exchange theory to distinguish procedural from interactional justice. Group Organization Management, 27: 324-351. 
Deutsch, M. 1975. Equity, equality, and need: What determines which value will be used as the basis of distributive justice? Journal of Social Issues, 31(3): 137-149.

Dittrich, J. E., \& Carrell, M. R. 1979. Organizational equity perceptions, employee job satisfaction, depatermental absence and turnover rates. Organizational Behavior and Human Performance, 24(1): 29-40.

Drake, D., \& Lawrence, J. 2000. Equality and distributions of inheritance in families. Social Justice Research, 13(3): 271-290.

Dyer, W. G. 1986. Cultural change in family firms: Understanding and managing business and family transitions. San Francisco: Jossey-Bass.

Dyer, W. G., \& Handler, W. 1994. Entrepreneurship and family business: Exploring the connections. Entrepreneurship Theory and Practice, 19(1): 71-83.

Ekeh, P. P. 1974. Social exchange theory: The two traditions. Cambridge, Mass.: Harvard University Press.

Festinger, L. 1954. A theory of social comparison processes. Human Relations, 7(2): 117-140.

Festinger, L. 1957. A theory of cognitive dissonance. New York: Harper and Row.

Folger, R., \& Skarlicki, D. P. 1999. Unfairness and resistance to change: Hardship as mistreatment. Journal of Organizational Change Management, 12(1): 35-50.

Fondacaro, M., Jackson, S., \& Luescher, J. 2002. Toward the assessment of procedural and distributive justice in resolving family disputes. Social Justice Research, 15(4): 341-371.

Friedman, S. 1991. Sibling relationships and intergenerational succession in family firms. Family Business Review, 4(1): 3-20.

Gagné, M., Sharma, P., \& De Massis, A. 2014. The study of organizational behaviour in family business. European Journal of Work and Organizational Psychology, 23(5): 643-656.

Goldman, B. 2003. The application of referent cognitions theory to legal-claiming by terminated workers: The role of organizational justice and anger. Journal of Management, 29(5): 705728.

Greenberg, J. 1988. Equity and workplace status: A field experiment. Journal of Applied Psychology, 73(4): 606-613.

Greenberg, J. 1990a. Employee theft as a reaction to underpayment inequity: The hidden cost of pay cuts. Journal of Applied Psychology, 75(5): 561-568.

Greenberg, J. 1990b. Organizational justice: Yesterday, today, and tomorrow. Journal of Management, 16(2): 399-432.

Hofstede, G. 1984. Cultural dimensions in management and planning. Asia Pacific Journal of Management, 1(2): 81-99.

Hofstede, G. 2016. Switzerland - Geert Hofstede. http://geert-hofstede.com/switzerland.html.

Homans, G. C. 1958. Social behavior as exchange. American Journal of Sociology, 63: 597606.

Homans, G. C. 1961. Social Behavior: Its Elementary Forms. New York: Harcourt, Brace.

Homburg, C., Klarmann, M., \& Schmitt, J. 2010. Brand awareness in business markets: When is it related to firm performance? International Journal of Research in Marketing, 27(3): 201-212.

Janssen, O. 2001. Fairness perceptions as a moderator in the curvilinear relationships between job demands, and job performance and job satisfaction. The Academy of Management Journal, 44(5): 1039-1050.

Jensen, M., \& Meckling, W. 1976. Theory of the firm: Managerial behavior, agency costs, and ownership structure. Journal of Financial Economy, 3: 305-350.

Journal, S. E., Wennberg, K., Wiklund, J., \& Nordqvist, M. 2011. Implications of intra-family and external ownership transfer of family firms: Performance differences. Strategic 
Entrepreneurship Journal, 372: 352-372.

Kahn, A., O’Leary, V., Krulewitz, J. E., \& Lamm, H. 1980. Equity and equality: Male and female means to a just end. Basic and Applied Social Psychology, 1(2): 173-197.

Kidwell, R., Kellermanns, F., \& Eddleston, K. 2012. Harmony, justice, confusion, and conflict in family firms: Implications for ethical climate and the "Fredo effect." Journal of Business Ethics, 106: 503-517.

Lansberg, I. 1988. The succession conspiracy. Family Business Review, 1(2): 119-143.

Lansberg, I., \& Astrachan, J. 1994. Influence of family relationships on succession planning and training: The importance of mediating factors. Family Business Review, 7(1): 39-59.

Le Breton-Miller, I. Le, \& Steier, L. P. 2004. Toward an integrative model of effective FOB succession. Entrepreneurship Theory and Practice, 28(4): 1042-2587.

Leventhal, G. S. 1980. What should be done with equity theory? New approaches to the study of fairness in social relationships. In K. Gergen, M. Greenberg, \& R. Willis (Eds.), Social exchange: Advances in theory and research: 27-55. New York: Plenum Press.

Leventhal, G. S., \& Anderson, D. 1970. Self-interest and the maintenance of equity. Journal of Personality and Social Psychology, 15(1): 57-62.

Leventhal, G. S., \& Lane, D. W. 1970. Sex, age, and equity behavior. Journal of Personality and Social Psychology, 15(4): 312-316.

Lifton, R. J. 1967. Death in life: Survivors of Hiroshima. New York: Random House.

Lind, E. A., Greenberg, J., Scott, K. S., \& Welchans, T. D. 2000. The winding road from employee to situational complainant: And psychological determinants of claims. Administrative Science Quarterly, 45: 557-590.

Lindell, M. K., \& Whitney, D. J. 2001. Accounting for common method variance in crosssectional research designs. Journal of Applied Psychology, 86(1): 114-121.

Lubatkin, M. H., Ling, Y., \& Schulze, W. 2007. An organizational justice-based view of selfcontrol and agency costs in family firms. Journal of Management Studies, 44(6): 955-971.

Lubatkin, M. H., Yan, L., \& Schulze, W. S. 2007. An organizational justice-based view of selfcontrol and agency costs in family firms. Journal of Management Studies, 44(6): 955-971.

Masterson, S. S., Lewis, K., Goldman, B. M., \& Taylor, M. S. 2000. Integrating justice and social exchange: The differing effects of fair procedures and treatment on work relationships. Academy of Management Journal, 43(4): 738-748.

McFarlin, D. B., \& Sweeney, P. D. 1992. Distributive and procedural justice as predictors of satisfaction with personal and organizational outcomes. The Academy of Management Journal, 35(3): 626-637.

Meindl, J. R. 1989. Managing to be fair: An exploration of values, motives, and leadership. Administrative Science Quarterly, 34(2): 252-276.

Mikula, G. 1993. On the experience of injustice. European Review of Social Psychology, 4(1): 223-244.

Mikula, G., Scherer, K. R., \& Athenstaedt, U. 1998. The role of injustice in the elicitation of differential emotional reactions. Personality Social Psychology Bulletin, 24(7): 769-783.

Morris, M., Williams, R., Allen, J., \& Avila, R. 1997. Correlates of success in family business transitions. Journal of Business Venturing, 12: 385-401.

Olson, D. H. 1986. Circumplex model VII: Validation studies and FACES III. Family Process, 25(3): 337-351.

Olson, D. H. 1991. Commentary: Three-dimensional (3-D) circumplex model and revised scoring of faces III. Family Process, 30(1): 74-79.

Parrot, G. W., \& Smith, R. H. 1993. Distinguishing the experiences of envy and jealousy. Journal of Personality and Social Psychology, 64(6): 906-920. 
Podsakoff, P. M., MacKenzie, S. B., Lee, J.-Y., \& Podsakoff, N. P. 2003. Common method biases in behavioral research: A critical review of the literature and recommended remedies. The Journal of Applied Psychology, 88(5): 879-903.

Punch, K. F., \& Oancea, A. 2014. Introduction to research methods in education (2nd ed.). Los Angeles, London, New Delhi, Singapore, Washington DC: SAGE Publications.

Rosenblatt, M., de Mik, L., Anderson, R. M., \& Johnson, P. 1985. The family in business: Understanding and dealing with the challenges entrepreneurial families face. San Francisco: Jossey-Bass.

Schulze, W. S., Lubatkin, M. H., \& Dino, R. N. 2002. Altruism, agency, and the competitiveness of family firms. Managerial and Decision Economics, 23(4-5): 247-259.

Schulze, W. S., Lubatkin, M. H., \& Dino, R. N. 2003a. Toward a theory of agency and altruism in family firms. Journal of Business Venturing, 18(4): 473-490.

Schulze, W. S., Lubatkin, M. H., \& Dino, R. N. 2003b. Exploring the agency consequences of ownership dispersion among the directors of private family firms. Academy of Management Journal, 46(2): 179-194.

Schulze, W. S., Lubatkin, M. H., Dino, R. N., \& Buchholtz, A. K. 2001a. Agency relationships in family firms: Theory and evidence. Organization Science, 12(2): 99-116.

Schulze, W. S., Lubatkin, M. H., Dino, R. N., \& Buchholtz, A. K. 2001b. Agency relationships in family firms. Organization Science, 12(2): 99-116.

Sharma, P., Chrisman, J. J., \& Chua, J. H. 1997. Strategic management of the family business: Past research and future challenges. Family Business Review, 10(1): 1-35.

Smith, C. A., Haynes, K. N., Lazarus, R. S., \& Pope, L. K. 1993. In search of the“ hot” cognitions: attributions, appraisals, and their relation to emotion. Journal of Personality and Social Psychology, 65(5): 916-929.

Taylor, J. E., \& Norris, J. E. 2000. Sibling relationships, fairness, and conflict over transfer of the farm. Family Relations, 49(3): 277-283.

Thibaut, J. W., \& Kelley, H. H. 1959. The social psychology of groups. New York: Wiley.

Thibaut, J., \& Walker, L. 1978. A theory of procedure. California Law Review, 66: 541-566.

Tornblom, K. Y., \& Foa, U. G. 1983. Choice of a distribution principle: Crosscultural evidence on the effects of resources. Acta Sociologica, 26(2): 161-173.

Van der Heyden, L., Blondel, C., \& Carlock, R. S. 2005. Fair process: Striving for justice in family business. Family Business Review, 18(1): 1-21.

Van Doorn, J., \& Verhoef, P. C. 2008. Critical incidents and the impact of satisfaction on customer share. Journal of Marketing, 72: 123-142.

Wade-Benzoni, K. A. 2002. A golden rule over time: Reciprocity in intergenerational allocation decisions. Academy of Management Journal, 45: 1011-1028.

Walker, L., Lind, E. A., \& Thibaut, J. 1979. Relation between procedural and distributive justice. Virginia Law Review, 65(8): 1401-1420.

Walsh, J. P., \& Seward, J. K. 1990. On the efficiency of internal and external corporate control mechanisms. Academy of Management Review, 15(3): 421-458.

Ward, J. L. 1997. Growing the family business: Special challenges and best practices. Family Business Review, 10(4): 323-337.

Weiss, H. M., Suckow, K., \& Cropanzano, R. 1999. Effects of justice conditions on discrete emotions. Journal of Applied Psychology, 84(5): 786-794.

Wiklund, J., Nordqvist, M., Hellerstedt, K., \& Bird, M. 2013. Internal versus external ownership transition in family firms: An embeddedness perspective. Entrepreneurship Theory and Practice, 37(6): 1319-1340.

Yoshimura, C. G. 2010. The experience and communication of envy among siblings, siblings-in- 
law, and spouses. Journal of Social and Personal Relationships, 27(8): 1075-1088.

Zellweger, T., Richards, M., Sieger, P., \& Patel, P. C. 2015. How much am I expected to pay for my parents' firm? An institutional logics perspective on family discounts. Entrepreneurship Theory and Practice, 1-29.

Zhang, Y., Lepine, J. A., Buckman, B. R., \& Wei, F. 2014. It's not fair ... or is it? The role of justice and leadership in explaining work stressor-job performance relationships. Academy of Management Journal, 57(3): 675-697. 
Table 1: Descriptive Statistics and Correlations of Variables in Under-rewarded Scenario

\begin{tabular}{|c|c|c|c|c|c|c|c|c|c|c|c|c|c|c|c|c|c|c|c|c|c|c|c|c|c|c|}
\hline & Obs. & Mean $s$ & Std.Dev.M & $\operatorname{Min} \mathrm{N}$ & & $\mathrm{VIF}$ & 1 & 2 & 3 & 4 & 5 & 6 & 7 & 8 & 9 & 10 & 11 & 12 & 13 & 14 & 15 & 16 & 17 & 18 & 19 & \\
\hline 1 Perceived injustice & 602 & 5.63 & 1.76 & 1 & 77 & 0.98 & $\begin{aligned} 1 \\
02470 *\end{aligned}$ & & & & & & & & & & & & & & & & & & & \\
\hline $\begin{array}{l}2 \text { L Lssis work effort } \\
3 \text { Shirking }\end{array}$ & 596 & 3.73 & $\begin{array}{l}2.01 \\
1.94\end{array}$ & 1 & & n.a. & $\begin{array}{l}0.3479 * * \\
0.292 *\end{array}$ & $\begin{array}{r}1 \\
0.7750^{*}\end{array}$ & & & & & & & & & & & & & & & & & & \\
\hline 4 Free-riding & 594 & 3.82 & 1.81 & 1 & 7 & n.a. & $0.2942^{*}$ & $0.4804^{*}$ & $0.5530^{*}$ & 1 & & & & & & & & & & & & & & & & \\
\hline 5 Resistance to change & 601 & 2.61 & 1.62 & 1 & 7 & n.a. & $0.1529^{*}$ & $0.4466^{*}$ & $0.5002^{*}$ & $0.3883^{*}$ & 1 & & & & & & & & & & & & & & & \\
\hline 6 Legal claiming & 598 & 3.02 & 2.08 & 1 & 7 & n.a. & $0.4002^{*}$ & $0.4109^{*}$ & $0.4322^{*}$ & $0.3885^{*}$ & $0.4084^{*}$ & 1 & & & & & & & & & & & & & & \\
\hline 7 Combined injustice reduction mechanisms & 582 & 3.31 & 1.44 & 1 & 7 & n.a. & $0.4070^{*}$ & $0.8195^{*}$ & $0.8547^{*}$ & $0.7368^{*}$ & $0.6879^{*}$ & $0.7108^{*}$ & 1 & & & & & & & & & & & & & \\
\hline 8 Compensation father & 274 & 59.96 & 37.31 & 0 & 100 & n.a. & -0.0410 & 0.0752 & 0.0941 & 0.0018 & 0.0007 & $-0.1341^{*}$ & 0.0174 & 1 & & & & & & & & & & & & \\
\hline 9 Compensation brother & 274 & 40.04 & 37.31 & 0 & 100 & n.a. & 0.0410 & -0.0752 & -0.0941 & -0.0018 & -0.0007 & $0.1341^{*}$ & -0.0174 & $-1.0000^{*}$ & 1 & & & & & & & & & & & \\
\hline 10 No compensation & 503 & 0.45 & 0.50 & 0 & & n.a. & $-0.3417^{*}$ & $-0.2798^{*}$ & $-0.2467^{*}$ & $-0.2407^{*}$ & $-0.1533^{*}$ & $-0.4101^{*}$ & $-0.3484^{*}$ & & & 1 & & & & & & & & & & \\
\hline 11 Family cohesion & 1341 & 5.28 & 1.34 & 1 & 7 & n.a. & 0.0383 & -0.0502 & -0.0248 & 0.0022 & 0.0259 & 0.0282 & -0.0146 & $-0.1504^{*}$ & $0.1504^{*}$ & 0.0219 & 1 & & & & & & & & & \\
\hline 12 Anger & 603 & 5.14 & 1.83 & 1 & & n.a. & $0.7718^{*}$ & $0.4162^{*}$ & $0.4085^{*}$ & $0.3901^{*}$ & $0.3083^{*}$ & $0.4624^{*}$ & $0.5208^{*}$ & 0.0261 & -0.0261 & $-0.3378 *$ & 0.0155 & 1 & & & & & & & & \\
\hline 13 Envy & 596 & 4.24 & 2.01 & 1 & 7 & n.a. & $0.4465^{*}$ & $0.4818^{*}$ & $0.4399 *$ & $0.3654^{*}$ & $0.3380^{*}$ & $0.3705^{*}$ & $0.5172^{*}$ & 0.0742 & -0.0742 & $-0.3002 *$ & 0.0459 & $0.5393^{*}$ & 1 & & & & & & & \\
\hline 14 Industry & 1381 & 0.55 & 0.50 & 0 & 1 & 0.95 & 0.0366 & 0.0336 & 0.0063 & 0.0023 & 0.0136 & 0.0340 & 0.0241 & 0.0601 & -0.0601 & -0.0667 & -0.0063 & 0.0100 & 0.027 & 1 & & & & & & \\
\hline 15 Firm size & 1417 & 27.29 & 35.83 & 0 & 250 & 0.94 & 0.0507 & 0.0374 & 0.0492 & $0.0918^{*}$ & -0.0116 & -0.0204 & 0.0453 & -0.0177 & 0.0177 & -0.0249 & -0.0055 & 0.0527 & $0.1136^{*}$ & $-0.1359^{*}$ & 1 & & & & & \\
\hline 16 Firm age & 1365 & 43.91 & 36.02 & 1 & 328 & 0.95 & -0.0176 & 0.0556 & 0.0263 & -0.0117 & -0.0475 & $-0.1331^{*}$ & -0.0194 & $0.1477^{*}$ & $-0.1477^{*}$ & 0.0809 & 0.0088 & -0.0406 & -0.027 & $-0.1794^{*}$ & $0.2454^{*}$ & & & & & \\
\hline 17 Performance & 1244 & 0.06 & 0.38 & -1 & & 0.99 & -0.0074 & -0.0004 & 0.0056 & -0.0735 & 0.0011 & $-0.0884^{*}$ & -0.0432 & 0.0919 & -0.0919 & -0.0186 & 0.0050 & -0.0495 & 0.000 & 0.053 & -0.025 & $-0.1145^{*}$ & 1 & & & \\
\hline 18 Age respondent & 1274 & 53.65 & 10.25 & 24 & 90 & 0.95 & $-0.1165^{*}$ & -0.0523 & -0.0357 & 0.0488 & -0.0727 & -0.0407 & -0.0350 & -0.0357 & 0.0357 & 0.0077 & -0.0223 & -0.0721 & $-0.1448^{*}$ & 0.046 & $-0.0760^{*}$ & 0.050 & -0.030 & 1 & & \\
\hline 19 Region & 1417 & 0.23 & 0.42 & 0 & 1 & 0.99 & -0.0718 & $0.1018^{*}$ & $0.1487^{*}$ & 0.0420 & 0.0391 & $0.1236^{*}$ & $0.1134^{*}$ & 0.0114 & -0.0114 & 0.0191 & 0.0347 & -0.0264 & -0.078 & 0.017 & $-0.0618^{*}$ & -0.030 & -0.050 & 0.050 & 1 & \\
\hline 20 Gender & 1281 & 0.10 & 0.30 & 0 & & 0.96 & 0.0295 & -0.0537 & -0.037 & $\begin{array}{l}-0.0794 \\
-0.07\end{array}$ & -0.0038 & -0.0278 & -0.0661 & 0.0652 & -0.0652 & 0.0710 & $0.0640^{*}$ & & & $0.1455^{*}$ & $-0.0895^{*}$ & & -0.011 & & 0.020 & \\
\hline
\end{tabular}

Table 2: Descriptive Statistics and Correlations of Variables in Over-rewarded Scenario

\begin{tabular}{|c|c|c|c|c|c|c|c|c|c|c|c|c|c|c|c|c|c|c|c|c|c|}
\hline & Obs. & Mean & Std.Dev. & $\overline{\operatorname{Min} 1}$ & Max & VIF & 1 & 2 & 3 & 4 & 5 & 6 & 7 & 8 & 9 & 10 & 11 & 12 & 13 & 14 & 15 \\
\hline 1 Perceived injustice & 589 & 5.17 & 1.97 & 1 & & 0.98 & 1 & & & & & & & & & & & & & & \\
\hline 2 More work effort & 586 & 4.33 & 1.95 & 1 & 71 & n.a. & 0.0706 & 1 & & & & & & & & & & & & & \\
\hline 3 Less job satisfaction & 584 & 2.77 & 1.81 & 1 & 71 & n.a. & $0.3132 *$ & $0.1410^{*}$ & 1 & & & & & & & & & & & & \\
\hline 4 Salary increase to under-rewarded & 587 & 5.05 & 1.64 & 1 & 7 & n.a. & $0.4287^{*}$ & $0.1663^{*}$ & $0.3097 *$ & 1 & & & & & & & & & & & \\
\hline 5 Toleration of less work effort & 585 & 2.48 & 1.56 & 1 & 7 & n.a. & $0.1850^{*}$ & $0.1626^{*}$ & $0.2836^{*}$ & $0.2916^{*}$ & 1 & & & & & & & & & & \\
\hline 6 Combined injustice reduction mechansims & 580 & 3.65 & 1.12 & 1 & 7 & & $0.3884^{*}$ & $0.6084^{*}$ & $0.6763^{*}$ & $0.6638^{*}$ & $0.6382^{*}$ & 1 & & & & & & & & & \\
\hline 7 Family cohesion & 1341 & 5.28 & 1.34 & 1 & & n.a. & $0.1325^{*}$ & 0.0184 & -0.0098 & $0.1669^{*}$ & 0.0508 & 0.0772 & 1 & & & & & & & & \\
\hline 8 Guilt & 589 & 4.89 & 2.04 & 1 & 7 & n.a. & $0.6567 *$ & $0.1676^{*}$ & $0.3323^{*}$ & $0.3620^{*}$ & $0.2260^{*}$ & $0.4210^{*}$ & $0.1642^{*}$ & 1 & & & & & & & \\
\hline 9 Industry & 1381 & 0.55 & 0.50 & 0 & 10 & 0.91 & 0.0217 & 0.0508 & 0.009 & 0.0414 & 0.0245 & 0.0435 & -0.0063 & 0.0432 & 1 & & & & & & \\
\hline 10 Firm size & 1417 & 27.29 & 35.83 & 0 & 2500 & 0.91 & 0.016 & -0.0304 & -0.0312 & -0.0103 & $\begin{array}{l}-0.0185 \\
-\end{array}$ & $\begin{array}{l}-0.0332 \\
-0.033\end{array}$ & -0.0055 & 0.0334 & $-0.1359^{*}$ & 1 & & & & & \\
\hline 11 Firm age & 1365 & 43.91 & 36.02 & 1 & $328 \mathrm{o}$ & 0.87 & $-0.1040^{*}$ & 0.0052 & -0.0273 & $-0.1288^{*}$ & -0.0058 & $\begin{array}{l}-0.0549 \\
-0.059\end{array}$ & 0.0088 & -0.0659 & $-0.1794 *$ & $0.2454^{*}$ & 1 & & & & \\
\hline 12 Performance & 1244 & 0.06 & 0.38 & -0.7 & & 0.97 & 0.0188 & -0.0734 & 0.0168 & -0.0344 & -0.0431 & -0.0527 & 0.005 & -0.0587 & 0.053 & -0.0254 & $-0.1145 *$ & 1 & & & \\
\hline 13 Age respondent & 1274 & 53.65 & 10.25 & 24 & & & -0.0273 & 0.0316 & 0.0099 & 0.0344 & -0.0429 & 0.0057 & -0.0223 & -0.0651 & 0.0459 & $-0.0760^{*}$ & 0.05 & -0.0299 & 1 & & \\
\hline 14 Region & 1417 & 0.23 & 0.42 & 0 & & 0.98 & -0.0208 & $0.1828^{*}$ & $-0.1252^{*}$ & -0.0211 & $0.1198 *$ & 0.0655 & 0.0347 & -0.002 & 0.0169 & $-0.0618^{*}$ & -0.0297 & -0.0502 & 0.04 & & \\
\hline 15 Gender & 1281 & 0.10 & 0.30 & 0 & & 1.03 & 0.0529 & 0.0229 & $0.0855^{*}$ & $0.0970^{*}$ & 0.0316 & $0.0866^{*}$ & $0.0640^{*}$ & $0.1070^{*}$ & $0.1455^{*}$ & $-0.0895^{*}$ & -0.0516 & -0.0114 & $-0.1376^{*}$ & 0.0198 & \\
\hline
\end{tabular}


Table 3: Models under-rewarded scenario

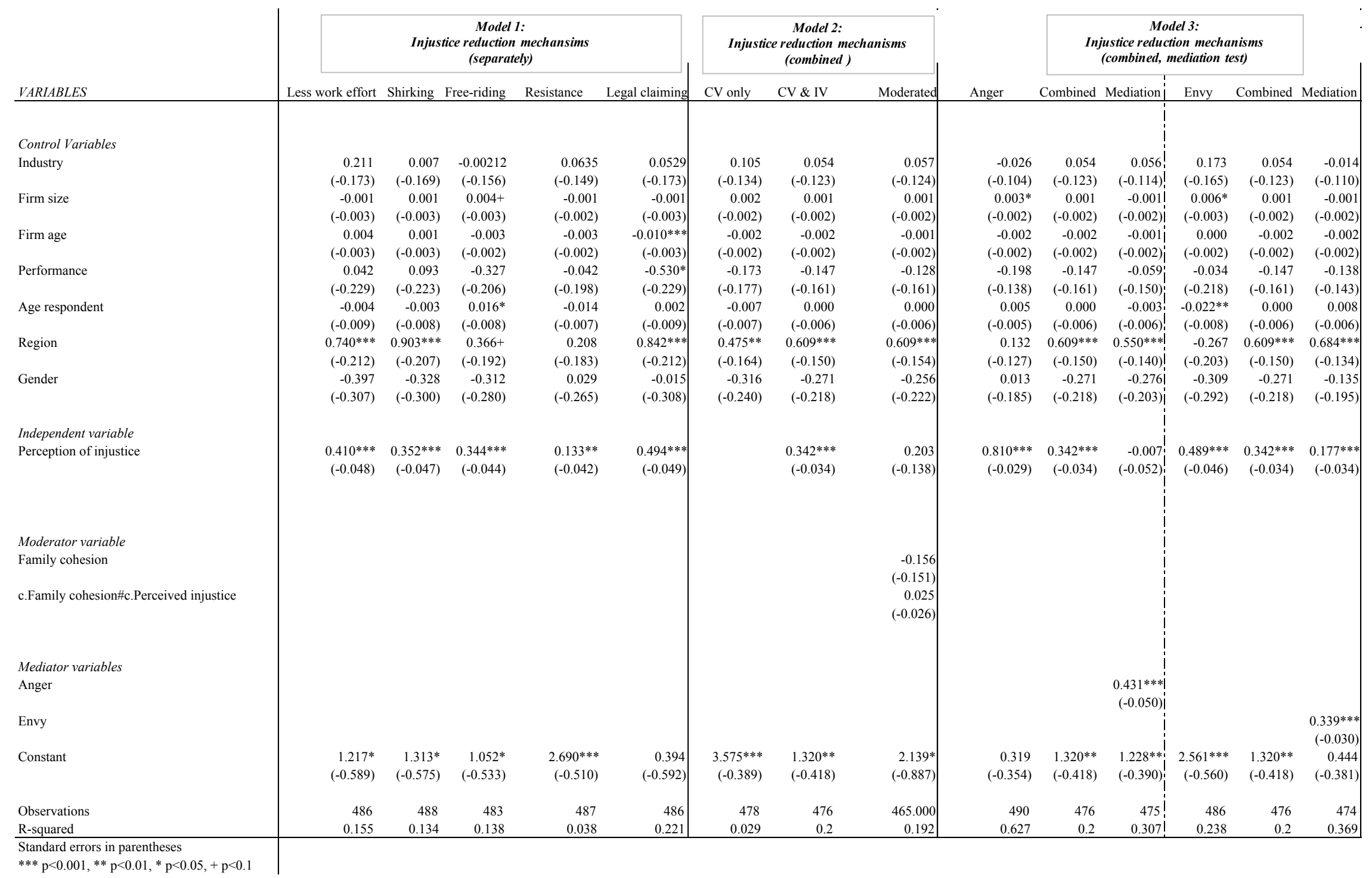


Table 4: Models over-rewarded scenario

\begin{tabular}{|c|c|c|c|c|c|c|c|c|c|c|}
\hline \multirow[b]{2}{*}{ VARIABLES } & \multirow[b]{2}{*}{ More work effort } & \multicolumn{2}{|c|}{$\begin{array}{c}\text { Model 4: } \\
\text { Injustice reduction mechansims } \\
\text { (separately) }\end{array}$} & \multirow[b]{2}{*}{ Toleration less work effort } & \multicolumn{2}{|c|}{$\begin{array}{c}\text { Model 5: } \\
\text { Injustice reduction mechanism } \\
\text { (combined) }\end{array}$} & \multirow[b]{2}{*}{ Moderator } & \multicolumn{3}{|c|}{$\begin{array}{c}\text { Model 6: } \\
\text { Injustice reduction mechanisms } \\
\text { (combined, mediation test) }\end{array}$} \\
\hline & & Less job satisfaction & Salary increase & & $\mathrm{CV}$ & IV \& CV & & OGuilt & Combined & Mediation \\
\hline Control variables & & & & & & & & & & \\
\hline Industry & $\begin{array}{r}0.217 \\
(-0.179)\end{array}$ & $\begin{array}{r}0.015 \\
(-0.158)\end{array}$ & $\begin{array}{r}-0.037 \\
(-0.140)\end{array}$ & $\begin{array}{r}0.009 \\
(-0.143)\end{array}$ & $\begin{array}{r}0.030 \\
(-0.105)\end{array}$ & $\begin{array}{r}0.041 \\
(-0.097)\end{array}$ & $\begin{array}{r}0.085 \\
(-0.100)\end{array}$ & $\begin{array}{r}0.181 \\
(-0.146)\end{array}$ & $\begin{array}{r}0.041 \\
(-0.097)\end{array}$ & $\begin{array}{r}0.013 \\
(-0.095)\end{array}$ \\
\hline Firm size & $\begin{array}{r}0.000 \\
(-0.002)\end{array}$ & $\begin{array}{r}-0.002 \\
(-0.002)\end{array}$ & $\begin{array}{r}0.000 \\
-0.002\end{array}$ & $\begin{array}{r}0.000 \\
(-0.002)\end{array}$ & $\begin{array}{r}0.000 \\
(-0.001)\end{array}$ & $\begin{array}{r}-0.001 \\
(-0.001)\end{array}$ & $\begin{array}{r}-0.001 \\
(-0.001)\end{array}$ & $\begin{array}{r}0.002 \\
(-0.002)\end{array}$ & $\begin{array}{r}-0.001 \\
(-0.001)\end{array}$ & $\begin{array}{r}-0.001 \\
(-0.001)\end{array}$ \\
\hline Firm age & $\begin{array}{r}0.001 \\
(-0.002)\end{array}$ & $\begin{array}{r}0.001 \\
(-0.002)\end{array}$ & $\begin{array}{r}-0.00397 * \\
-0.002\end{array}$ & $\begin{array}{r}-0.001 \\
(-0.002)\end{array}$ & $\begin{array}{r}-0.002 \\
(-0.001)\end{array}$ & $\begin{array}{r}-0.001 \\
(-0.001)\end{array}$ & $\begin{array}{r}-0.001 \\
(-0.001)\end{array}$ & $\begin{array}{r}-0.001 \\
(-0.002)\end{array}$ & $\begin{array}{r}-0.001 \\
(-0.001)\end{array}$ & $\begin{array}{r}0.000 \\
(-0.001)\end{array}$ \\
\hline Performance & $\begin{array}{l}-0.325+ \\
(-0.191)\end{array}$ & $\begin{array}{r}0.013 \\
(-0.169)\end{array}$ & $\begin{array}{r}-0.193 \\
(-0.150)\end{array}$ & $\begin{array}{r}-0.148 \\
(-0.153)\end{array}$ & $\begin{array}{r}-0.153 \\
(-0.111)\end{array}$ & $\begin{array}{r}-0.159 \\
(-0.104)\end{array}$ & $\begin{array}{r}-0.121 \\
(-0.108)\end{array}$ & $\begin{array}{l}-0.349^{*} \\
(-0.156)\end{array}$ & $\begin{array}{r}-0.159 \\
(-0.104)\end{array}$ & $\begin{array}{r}-0.106 \\
(-0.101)\end{array}$ \\
\hline Age respondent & $\begin{array}{r}0.010 \\
(-0.009)\end{array}$ & $\begin{array}{r}-0.003 \\
(-0.008)\end{array}$ & $\begin{array}{r}0.011 \\
(-0.007)\end{array}$ & $\begin{array}{r}-0.0133+ \\
(-0.008)\end{array}$ & $\begin{array}{r}0.002 \\
(-0.006)\end{array}$ & $\begin{array}{r}0.000 \\
(-0.005)\end{array}$ & $\begin{array}{r}0.001 \\
(-0.005)\end{array}$ & $\begin{array}{r}-0.005 \\
(-0.008)\end{array}$ & $\begin{array}{r}0.000 \\
(-0.005)\end{array}$ & $\begin{array}{r}0.001 \\
(-0.005)\end{array}$ \\
\hline Region & $\begin{array}{r}0.827 * * * \\
(-0.211)\end{array}$ & $\begin{array}{r}-0.560^{* *} \\
(-0.187)\end{array}$ & $\begin{array}{r}-0.031 \\
(-0.165)\end{array}$ & $\begin{array}{r}0.424^{*} \\
(-0.169)\end{array}$ & $\begin{array}{r}0.195 \\
(-0.123)\end{array}$ & $\begin{array}{r}0.177 \\
(-0.115)\end{array}$ & $\begin{array}{r}0.165 \\
(-0.119)\end{array}$ & $\begin{array}{r}0.071 \\
(-0.172)\end{array}$ & $\begin{array}{r}0.177 \\
(-0.115)\end{array}$ & $\begin{array}{r}0.166 \\
(-0.112)\end{array}$ \\
\hline Gender & $\begin{array}{r}-0.057 \\
(-0.300)\end{array}$ & $\begin{array}{r}0.372 \\
(-0.272)\end{array}$ & $\begin{array}{r}0.360 \\
(-0.235)\end{array}$ & $\begin{array}{r}-0.066 \\
(-0.245)\end{array}$ & $\begin{array}{r}0.201 \\
(-0.181)\end{array}$ & $\begin{array}{r}0.160 \\
(-0.170)\end{array}$ & $\begin{array}{r}0.191 \\
(-0.177)\end{array}$ & $\begin{array}{r}0.327 \\
(-0.245)\end{array}$ & $\begin{array}{r}0.160 \\
(-0.170)\end{array}$ & $\begin{array}{r}0.117 \\
(-0.166)\end{array}$ \\
\hline Independent variable & & & & & & & & & & \\
\hline Perceived injustice & $\begin{array}{r}0.062 \\
(-0.044)\end{array}$ & $\begin{array}{r}0.288^{* * *} \\
(-0.039)\end{array}$ & $\begin{array}{r}0.330^{* * * *} \\
(-0.035)\end{array}$ & $\begin{array}{r}0.141^{* * *} \\
(-0.036)\end{array}$ & & $\begin{array}{r}0.215^{* * *} \\
(-0.024)\end{array}$ & $\begin{array}{r}0.320^{* * *} \\
(-0.089)\end{array}$ & $\begin{array}{r}0.655^{* * *} \\
(-0.036)\end{array}$ & $\begin{array}{r}0.215^{* * * *} \\
(-0.024)\end{array}$ & $\begin{array}{r}0.115^{* * *} \\
(-0.030)\end{array}$ \\
\hline Moderator variable & & & & & & & & & & \\
\hline $\begin{array}{l}\text { Family cohesion } \\
\text { c.Family cohesion\#c.Perceived injustice }\end{array}$ & & & & & & & $\begin{array}{r}0.139 \\
(-0.087) \\
-0.022 \\
(-0.016)\end{array}$ & & & \\
\hline $\begin{array}{l}\text { Mediator variable } \\
\text { Guilt }\end{array}$ & & & & & & & & & & $0.153^{* * *}$ \\
\hline Constant & $\begin{array}{r}3.154 * * * \\
(-0.581)\end{array}$ & $\begin{array}{l}1.493^{* *} \\
(-0.517)\end{array}$ & $\begin{array}{r}2.964 * * * \\
(-0.456)\end{array}$ & $\begin{array}{r}2.389 * * * \\
(-0.469)\end{array}$ & $\begin{array}{r}3.581 * * * \\
(-0.317)\end{array}$ & $\begin{array}{r}2.502 * * * \\
(-0.320)\end{array}$ & $\begin{array}{l}1.764 * * \\
(-0.566)\end{array}$ & $\begin{array}{r}1.689^{* * * *} \\
(-0.474)\end{array}$ & $\begin{array}{r}2.502^{* * * *} \\
(-0.320)\end{array}$ & $\begin{array}{r}(-0.0291) \\
2.233^{* * *} \\
(-0.316)\end{array}$ \\
\hline Observations & 502 & 500 & 502 & 500 & 498 & 496 & 470 & 503 & 496 & 496 \\
\hline R-squared & 0.049 & 0.120 & 0.181 & 0.051 & 0.018 & 0.154 & 0.152 & 0.414 & 0.154 & 0.199 \\
\hline
\end{tabular}

Standard errors in parenthese

*** $\mathrm{p}<0.001,{ }^{* *} \mathrm{p}<0.01,{ }^{*} \mathrm{p}<0.05,+\mathrm{p}<0.1$ 